\section{Infusion of shrunken-2 Sweet Corn Seed with Organic Solvents: Effects on Germination and Vigor}

\author{
Patricia E. Hung ${ }^{1}$ \\ Department of Horticultural Science, University of Minnesota, St. Paul, \\ MN 55108
}

\author{
Vincent A. Fritz ${ }^{2}$ \\ Southern Experiment Station, University of Minnesota, Waseca, \\ MN 56093
}

\author{
Luther Waters, Jr. \\ Department of Horticultural Science, University of Minnesota, St. Paul, \\ MN 55108
}

\author{
Additional index words. supersweet corn, permeation, Zea mays, stand establishment, \\ seed vigor
}

\begin{abstract}
Sweet corn (Zea mays L. var. rugosa Bonaf.) seed carrying the mutant endosperm gene shrunken-2 $\left(s h_{2}\right)$ are very susceptible to seed rot and pre- and postemergence damping off. Experiments were conducted to determine if selected organic solvents were suitable carriers for fungicide infusion of $s h_{2}$ sweet corn seed for improved germination and stand establishment. Seed of 'Florida Staysweet' and 'Crisp-n-Sweet 710' were immersed in acetone, cyclohexane, decahydronaphthalene (Decalin), dimethylsulfoxide (DMSO), ethanol, or xylene for 5 seconds, $0.25,0.50,1.0,2.0,4.0$, or 8.0 hours, air-dried, and subjected to a cold-stress test. Total germination and percentage of normal seedlings in both cultivars were significantly decreased after 8 hours of immersion in acetone. Average seedling dry weight, however, did not decrease. DMSO was highly toxic to both cultivars. Ethanol increased seed mortality with increasing immersion times. Cyclohexane, Decalin, and xylene caused erratic responses in all measured variables as immersion time increased. In a second experiment, the effects of immersion time up to 4 hours in acetone on germination and vigor of $11 s h_{2}$ cultivars were compared. There was no correlation between cultivar germination or vigor and immersion in acetone. Results indicate acetone could be used to infuse fungicides into the seed of some $s h_{2}$ cultivars without compromising seed germination or vigor. However, each $s h_{2}$ cultivar must be screened individually to determine if it is a suitable candidate for organic solvent infusion of fungicides.
\end{abstract}

Sweet corn seed carrying the mutant endosperm gene shrunken-2 $\left(s h_{2}\right)$ exhibit poor germination and seedling vigor (Styer et al., 1980). Susceptibility to seed- and soil-borne pathogens is a major contributing factor. Conventional fungicide seed treatments, such as aqueous suspensions and powders, have been used to improve germination and seedling vigor of the $s h_{2}$ genotypes (Guzman et al., 1983; Pieczarka and Wolf, 1978).

An alternative is the infusion of fungicides via organic solvents. Because organic solvents are nonpolar, they easily penetrate the seedcoat, carrying nonpolar chemicals, including many fungicides, with them (Meyer and Mayer, 1971). Organic solvents volatil-

\footnotetext{
Received for publication 10 May 1991. Accepted for publication'27 Dec. 1991. Minnesota Agr. Expt. Sta. Journal Series no. 19,105. The cost of publishing this paper was defrayed in part by the payment of page charges. Under postal regulations, this paper therefore must be hereby marked $a d$ vertisement solely to indicate this fact.

'Graduate Assistant.

${ }^{2}$ Associate Professor.

${ }^{3}$ Professor. Current address: Dept. of Horticulture, The Ohio State Univ., Columbus, OH 43210.
}

reported for other crops (Daniels, 1983; Halloin and Minton, 1977; Muchovej, 1987).

Before a fungicide can be applied with the OSIT method, solvent effects on seed germinability and vigor need to be determined. Experiments with diverse crops [Dey (Pathak) and Mukherjee, 1988; Lewis et al., 19791 show that results depend on the crop species, the solvent used, and the duration of immersion.

We found no published information concerning the effect of immersion in an organic solvent on $s h_{2}$ sweet corn seed. Our intent was to identify at least one solvent that interferes as little as possible with germination and seedling quality so that future studies could focus directly on the effect of infused fungicides on these factors. The present research was undertaken to a) determine the effect of immersion in selected organic solvents for various lengths of time on germination and vigor of $s h_{2}$ sweet corn seed, and b) ascertain whether $s h_{2}$ cultivars of varying vigor ratings react in the same manner when exposed to a suitable solvent.

Nontreated seed of 11 cultivars of $s h_{2}$ hybrids, supplied by commercial seed producers in southwestern Idaho, were stored in a controlled environment facility at 8 to $10 \mathrm{C}$ and $33 \%$ relative humidity. Solvent treatment tests were carried out within 6 months of harvest. A randomized complete block design was used in each experiment. Treatments consisted of four replicates of 50 seeds each. Data were subjected to linear regression or analysis of variance; mean differences were determined using Fisher's protected least significant difference.

Solvent screening. Acetone, cyclohexane, decahydronaphthalene (Decalin, Aldrich Chemical, Milwaukee, Wis.), dimethylsulfoxide (DMSO), ethanol, and xylene were screened for effects on germination and vigor of 'Florida Staysweet' and 'Crisp-n-Sweet 710 '. Seed were soaked for $5 \mathrm{sec}$, or 0.25 , $0.5,1.0,2.0,4.0$, or $8.0 \mathrm{~h}$ in one of each of the solvents and air-dried overnight. Nontreated seed of each cultivar served as controls. Using the ragdoll method, all seeds were subjected to the modified seedlinggrowth cold test (SGCT) (Waters and Blanchette, 1983). The samples were incubated at $10 \mathrm{C}$ for 4 days followed by an additional 4 days at $25 \mathrm{C}$. At the end of the incubation period, the number of germinated seed and the number of normal seedlings were determined according to standard procedures (Intl. Seed Testing Assn., 1976). Average seedling dry weight, a measure of seedling vigor, was based on dried roots and shoots of normal seedlings. Germination and normal seedling percentages were transformed using an arcsin square root transformation and analyzed. No differences from original data were observed. Results herein are reported using original data.

Acetone did not cause a significant decrease in germination (nontreated control, 92\%, 'Florida Staysweet'; 94\%, 'Crisp-nSweet 710 ') or percent normal seedlings (nontreated control, 76\%, 'Florida Staysweet'; $81 \%$, 'Crisp-n-Sweet 710') of either 


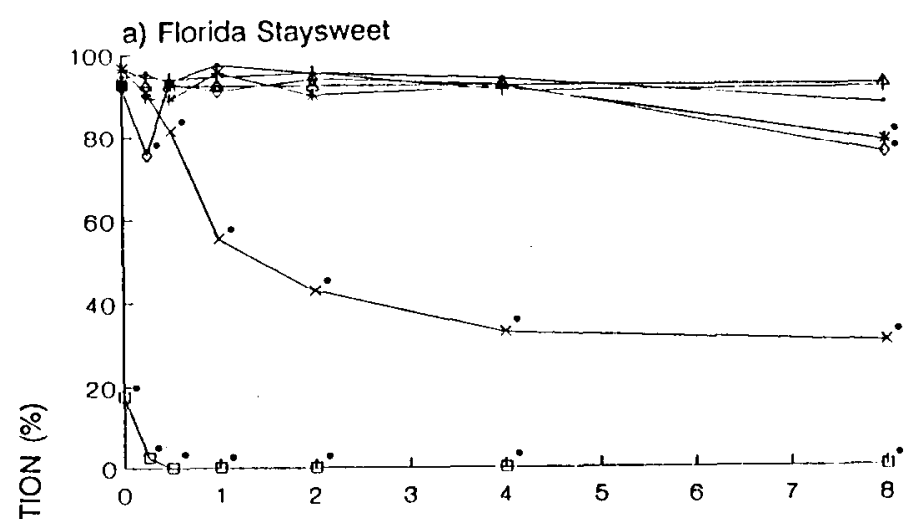

b) Crisp-n-Sweet 710

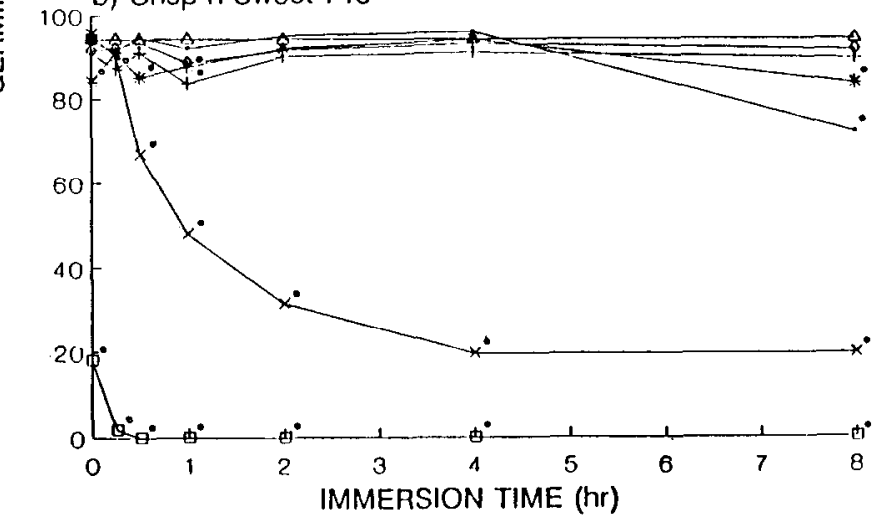

Fig. 1. Effect of solvent immersion on germination of 'Florida Staysweet' (a) and 'Crisp-n-Sweet $710^{\prime}$ ' (b) $s h_{2}$ sweet corn seed subjected to the modified seedling-growth control test. An open circle $\left({ }^{\circ}\right)$ indicates a value significantly different $(P \leq 0.05)$ from control value according to Fisher's protected LSD. ( - , acetone; -|-, cyclohexanc; -*-, decalin; - - DMSO; $\star-$, ethanol; $\triangleleft$, xylene; $\triangle$ - control).

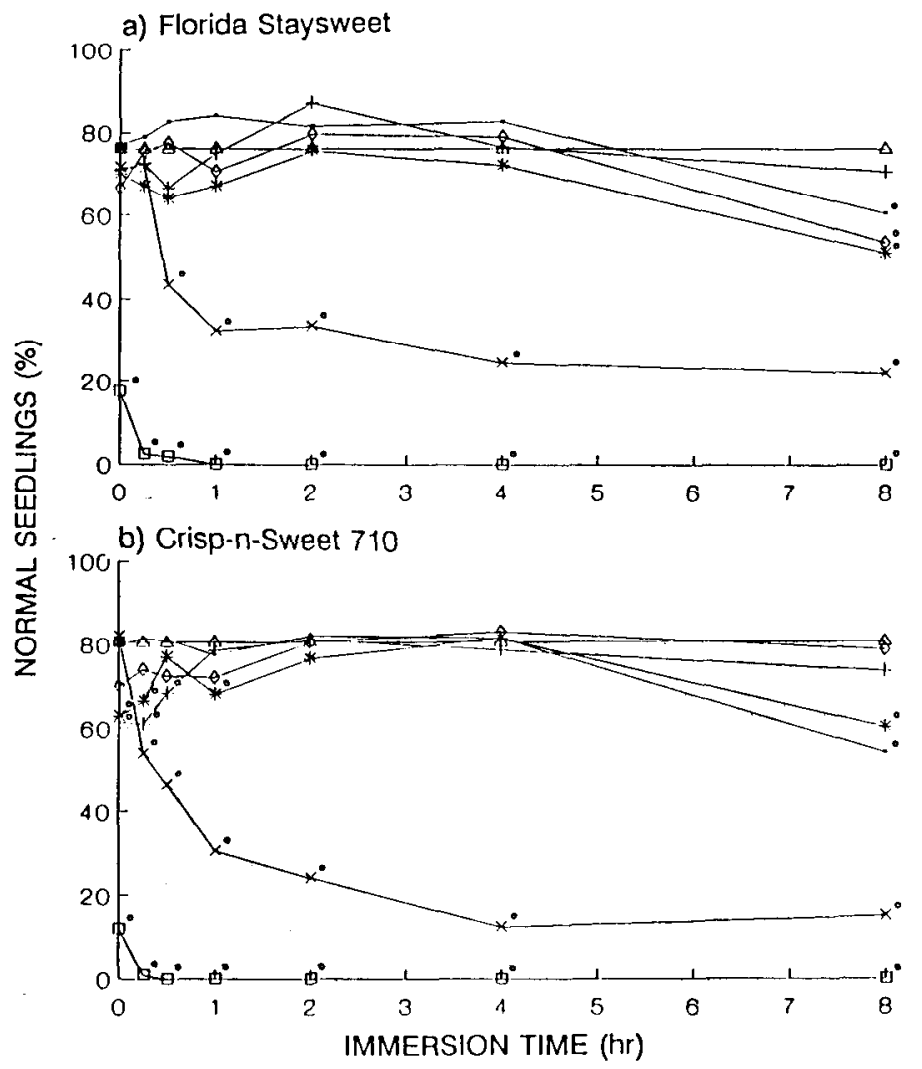

Fig. 2. Effect of solvent immersion on percentage of normal seedlings of 'Florida Staysweet' (a) and 'Crisp-n-Sweet 710' (b) $s h_{2}$ sweet corn seed subjected to the modified seedling-growth control test. An open circle $\left({ }^{\circ}\right)$ indicates a value significantly different $(P \leq 0.05)$ from control value according to Fisher's protected LSD. (---, acetone; -1 , cyclohexane; ${ }^{-*-}$, decalin; $\square$, DMSO; $*-$, ethanol; $\diamond$, xylene; $\triangle$, control). cultivar up to a 4 -h immersion; $8 \mathrm{~h}$ was detrimental (61\% and 54\%, 'Florida Staysweet' and 'Crisp-n-Sweet 710', respectively) (Figs. $1 \mathrm{a}$ and $\mathrm{b}, 2 \mathrm{a}$ and $\mathrm{b})$. These results contrast with those of Dey and Mukhejee (1988), which showed that dent corn seed immersed in acetone up to $8 \mathrm{~h}$ caused no ill effects on germinability following accelerated aging under $100 \%$ relative humidity and 40C. Both cultivars showed an increase in average seedling dry weight for all soak times with acetone when compared with nontreated controls; in six cases the increase was significant (Fig. $3 \mathrm{a}$ and $\mathrm{b}$ ).

DMSO and ethanol were more harmful than the other solvents to both cultivars. With a 5 -sec immersion in DMSO, germination decreased 4-fold and the percentage of normal seedlings decreased 5-fold when compared with nontreated controls; longer immersion times were even more detrimental (Figs. 1 and 2). Seed of both cultivars immersed $\geq 1$ $\mathrm{h}$ in DMSO did not germinate (Fig. 1). Seeds of either cultivar were little affected by a 5sec immersion in ethanol; however, 'Crispn-Sweet 710' seed showed a significant decline in percentage of normal seedlings with a 0.25 -h immersion, and with $\geq 0.5 \mathrm{~h}$, seeds of both cultivars displayed a logarithmic decline in germination ('Florida Staysweet': y $=61.01-40.25 \log (\times), r^{2}=0.92$; 'Crispn-Sweet 710': y = 52.36 - $46.27 \log (x)$, $\left.r^{2}=0.92\right)$ and percentage of normal seedlings ('Florida Staysweet': $\mathrm{y}=42.31$ $28.97 \log (x), r^{2}=0.80$; 'Crisp-n-Sweet 710': $\left.\mathrm{y}=37.29-35.49 \log (\mathrm{x}), r^{2}=0.86\right)$ with increasing immersion times (Figs. $1 \mathrm{a}$ and $\mathrm{b}$, $2 \mathrm{a}$ and $\mathrm{b}$ ). Those seeds surviving the ethanol immersion, however, had $40 \%$ average increase in seedling dry weight over the controls. It may be that ethanol selectively killed seed with lower vigor, leaving only the more vigorously growing seed to contribute to the dry weight measurement. Toxicity of ethanol with short $(0.5-\mathrm{h})$ immersion time has also been reported for lettuce (Lactuca sativa $\mathrm{L}$.) and pepper (Cupsicum annuum L.) seed (Muchovej et al., 1980). DMSO and ethanol were eliminated as possible choices for infusion.

'Crisp-n-Sweet 710' seed immersed in cyclohexane, Decalin, or xylene exhibited an erratic response in germination, percentage of normal seedlings, and average seedling dry weight as immersion time increased (Figs. $1 \mathrm{a}$ and $\mathrm{b}, 2 \mathrm{a}$ and $\mathrm{b}, 3 \mathrm{a}$ and $\mathrm{b}$ ) and therefore were eliminated from further experiments. Of the six solvents examined, acetone produced the most consistent response and was the least harmful to the seed.

Cultivar trials. Acetone was tested for effect on germination and vigor of $11 s h_{2}$ cultivars of high, medium, and low seed vigor ratings. Vigor ratings were assigned according to percentage emergence under cold stress conditions in field trials conducted at Urbana, Ill. (Juvik et al., 1988). A vigor rating of "high" was assigned to those cultivars having an emergence percentage $>70 \%$ ('Crisp-n-Sweet 710', 'Landmark', 'SCH 4051', and 'Sweetie 82'); "medium" to those cultivars having an emergence percentage $>50 \%$ but $<60 \%$ ('Florida Staysweet', 'Il- 
a) Florida Staysweet

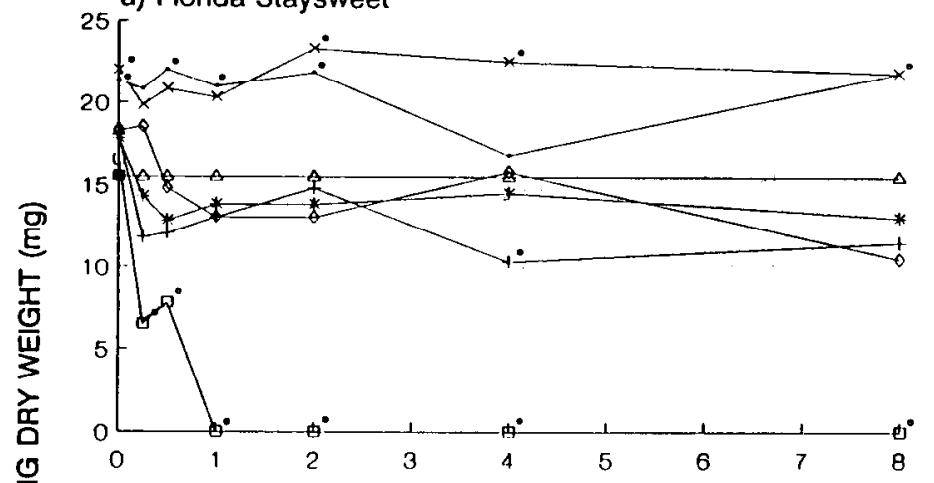

b) Crisp-n-Sweet 710

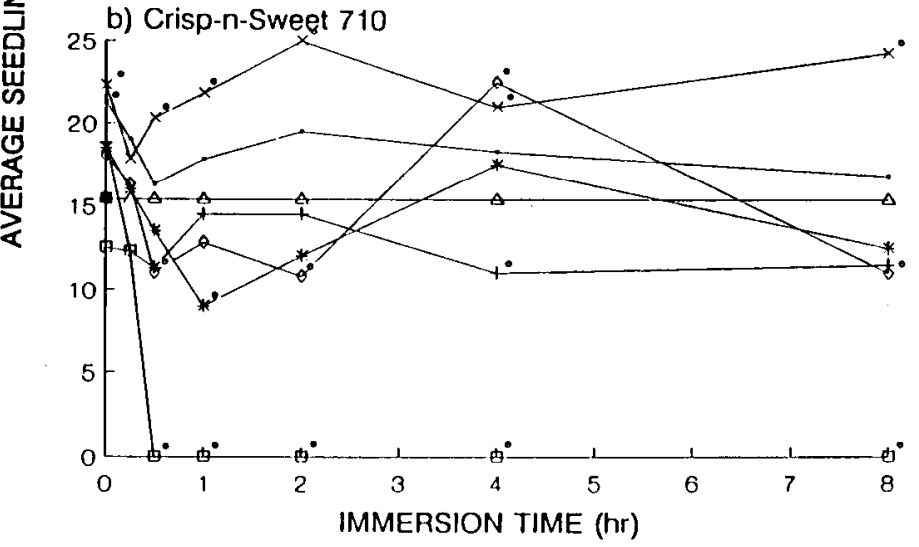

Fig. 3. Effect of solvent immersion on vigor of 'Florida Staysweet' (a) and 'Crisp-n-Sweet 710' (b) $s h_{2}$ sweet corn seed subjected to the modified seedling-growth control test. An open circle $\left(^{\circ}\right)$ indicates a value significantly different $(P \leq 0.05)$ from control value according to Fisher's protected LSD. (--, acetone; $-\mid-$, cyclohexane; $-*-$, decalin; - , DMSO; $-\star$, ethanol; $\triangleleft$, xylene; $\triangle$, control).

lini Gold', 'Summer Sweet 7200', and 'Zenith'); and "low" to those cultivars having an emergence percentage < 35\% ('Honey-nPearl', 'Ivory-n-Gold', and 'Sweetie 73'). Seed were soaked in acetone for $5 \mathrm{sec}$, or for $0.25,0.5,1.0,2.0$, or $4.0 \mathrm{~h}$ and then allowed to air-dry overnight. Nontreated seed of each cultivar served as controls. All were subjected to the modified SGCT; measurements were taken and analyzed as described in the solvent screening trial. Germination and normal seedling percentages were transformed using an arcsin square root transformation and analyzed. No differences from original data were observed. Results herein are reported using original data.

Cultivar response to cold stress in the field did not always correlate well with reaction to acetone treatment. Of the four high-vigor cultivars tested ('Crisp-n-Sweet 710', 'Landmark', 'SCH 4051', and 'Sweetie 82'), germination was significantly affected by acetone only in 'Landmark'; however, even in 'Landmark', the maximum difference between any two values was only $3 \%$. Percent normal seedlings was not significantly affected in any of the four high-vigor cultivars. 'SCH 4051' seed showed an increase in average seedling dry weight values for all acetone treatments over that of the control value $(18.8 \mathrm{mg})$; at 0.25 and $1.0 \mathrm{~h}$, the increase was significant $(24.3$ and $22.0 \mathrm{mg}$, respectively). 'Crisp-n-Sweet 710' seed immersed for $5 \mathrm{sec}$ had a significantly lower average seedling dry weight $(15.3 \mathrm{mg})$ than did the nontreated controls $(18.3 \mathrm{mg})$; seed im- mersed for $0.25 \mathrm{~h}$ had a significantly higher dry weight $(21.3 \mathrm{mg})$ than the control. 'Sweetie 82' seed immersed for $5 \mathrm{sec}$ also showed a significant decrease in average seedling dry weight $(17.0 \mathrm{mg})$ when compared with controls $(20.5 \mathrm{mg})$. All the other immersion times showed an increase over the controls.

Of the four medium-vigor cultivars tested, only 'Illini Gold' and 'Summer Sweet 7200' seed were not affected by immersion time in acetone when compared with nontreated controls. Normal seedlings of 'Zenith' seed showed an erratic response to increasing immersion time in acetone. A 0.25 -h immersion produced a significantly higher percentage of normal seedlings $(86 \%)$, and a 2.0-h immersion time produced significantly lower values $(63 \%)$ than the controls $(75 \%)$. In 'Florida Staysweet' seed, no significant differences were found in either germination or percentage of normal seedlings, although the average seedling dry weight of the nontreated controls $(20.0 \mathrm{mg})$ was significantly higher than that of seed immersed in acetone for $5 \mathrm{sec}(17.8 \mathrm{mg})$ or $0.5 \mathrm{~h}(17.5 \mathrm{mg})$.

Seed of the three low-vigor cultivars were also variable in their responses to soaking in acetone. Neither 'Honey-n-Pearl' nor 'Ivoryn-Gold' seed were significantly affected by any acetone treatment. However, 'Sweetie 73 ' seed immersed for $4 \mathrm{~h}$ had significantly lower germination $(57 \%)$ than nontreated controls $(70 \%)$; seed immersed for $0.25 \mathrm{~h}$ had two-thirds more normal seedlings (43\%) than the controls $(26 \%)$.
In general, the nontreated seed of these $s h_{2}$ cultivars displayed the same degree of germinability and vigor in the laboratory as in the field. Seed of cultivars that had a higher percentage germination also had a higher percentage of normal seedlings and higher average seedling dry weights than cultivars with lower percentage germination.

Results of this experiment show that there is wide variability among $s h_{2}$ cultivars in response to immersion in acetone. Seed quality of the high-vigor cultivars Landmark and SCH 4051, the medium-vigor cultivars Summer Sweet 7200 and Illini Gold, and the low-vigor cultivars Honeyn-Pearl and Ivory-n-Gold was not compromised by immersion in acetone for up to 4 h. Seedling vigor responses of the highvigor cultivars Crisp-n-Sweet 710 and Sweetie 82, and the medium-vigor cultivar Florida Staysweet were inconsistent with increasing lengths of time in acetone. The effect of acetone on the medium-vigor cultivar Zenith and the low-vigor cultivar Sweetie 73 was manifested through erratic germination and percentage of normal seedlings. These results suggest that seed vigor rating will not necessarily predict its performance after immersion in acetone.

'Crisp-n-Sweet 710' and 'Florida Staysweet' showed no adverse reaction to immersion in acetone up to $4 \mathrm{~h}$ in the solvent screening trial. However, in the cultivar trial, the results were not as consistent. Although germination and percentage of normal seedlings produced remained unaffected, the average seedling dry weight fluctuated substantially between experiments for both cultivars. The control values of the solvent trial increased considerably in the cultivar trial for both cultivars $(+4.5 \mathrm{mg}$, 'Florida Staysweet'; + 2.9 mg, 'Crisp-n-Sweet 710'), whereas most other soak times showed decreased seedling dry weight. The result was that the smallest values in the solvent trial (the control values) were among the highest values in the cultivar trials. However, different seed lots of 'Crisp-n-Sweet 710' and 'Florida Staysweet' were used in the two experiments. Previous observations indicate that response to a solvent soak may vary within a $s h$, cultivar by year and moisture content of the seed (K. Rushing, personal communication).

The solvent screening trials indicated that of the six solvents selected, acetone was the most innocuous to the seed, and, therefore, the most reliable for future study. The cultivar trials showed that immersion of several cultivars of $s h$, sweet corn in acetone for up to $4 \mathrm{~h}$ ('Crisp-n-Sweet 710', 'SCH 4051', 'Summer Sweet 7200', 'Florida Staysweet', 'Illini Gold', and 'Ivory-n-Gold'), which differ in vigor, can be done without harmful effects on germination or vigor. Previous studies have indicated that maximum uptake of a chemical via organic solvent infusion occurs within $1 \mathrm{~h}$ (Lewis et al., 1979; O'Neill et al., 1979). Acetone appears to be an ideal solvent to try in fungicide infusion of some cultivars of $s h_{2}$ sweet corn seed. 


\section{Literature Cited}

Daniels, B.A. 1983. Elimination of Fusarium moniliforme from corn seed. Plant Dis. Rptr. 67:609-611.

Dey (Pathak), G. and R.K. Mukherjee. 1988. Invigoration of dry seeds with physiologically active chemicals in organic solvents. Seed Sci. \& Technol. 16:145-153.

Guzman, V.L., E.A. Wolf, and F.G. Martin. 1983. Effect of a compensated-rate seeding and seed protectorants on yield and quality of a shrunken-2 sweet corn hybrid. HortScience 18:338 340 .

Halloin, J.M. and E.M. Minton. 1977. Use of methylene chloride for application of fungicides to cottonseed. Proc. Amer. Phytopathol. Soc. 4:156. (Abstr. 343)

International Seed Testing Association. 1976. The germination test. Seed Sci. \& Technol. 4:2328.

Juvik, J.A., W.H. Shoemaker, S.K. Douglass, and T.E. Young. 1988. Cold soil stress test for sweet corn. Ill. Veg. Res. Rpt. p. 88-92.
Lewis, J.A., G.C. Papavizas, and N.R. O'Neill. 1979. Effect of seed immersion in organic solvents on germinability. J. Agr. Sci. Camb. 92:563-570

Meyer, H. and A.M. Mayer. 1971. Permeation of dry seeds with chemicals; use of dichloromethane. Science 171:583-584.

Muchovej, J.J. 1987. Automotive ethanol for treatment of soybean seeds with fungicides. Seed Sci. \& Technol. 15:265-269.

Muchovej, J.J., O.D. Dhingra, and P.R.S. Carvalho. 1980. Organic solvents as vehicles for systemic and nonsystemic fungicides for vegetable seed treatment. Fitopatologia Brasileira. 5:337-341.

O'Neill, N.R., G.C. Papavizas, and J.A. Lewis. 1979. Infusion and translocation of systemic fungicides applied to seeds in acetone. Phytopathology 69:690-694.

Papavizas, G.C. and J.A. Lewis. 1976. Acetone infusion of pyroxychlor into soybean seed for the control of Phytophthora megasperma var. sojae. Plant Dis. Rptr. 60:484-488.

Papavizas, G.C., J.A. Lewis, R.D. Lumsden, P.B.
Adams, W.A. Ayers, and J.G. Kantzes. 1977. Control of pvthium blight on bean with ethazol and prothiocarb. Phytopathology 67:1293-1299.

Persson, B. 1988. Enhancement of seed germination by plant growth regulators infused via acetone. Seed Sci. \& Technol. 16:391-404.

Pieczarka. D.J. and E.A. Wolf. 1978. Increased stand of 'Florida Staysweet' corn by seed treatment with fungicides. Proc. Fla. State Hort. Soc. 91:290-291.

Styer, R.C., D.J. Cantliffe, and L.C. Hannah. 1980. Differential seed and seedling vigor in shrunken-2 compared to three other genotypes of corn at various stages of development. J. Amer. Soc. Hort. Sci, 105(3):329-332.

Tao, K.L., A.A. Khan, G.E. Harman, and C.J. Eckenrode. 1974. Practical significance of the application of chemicals in organic solvents to dry seeds, J. Amer. Soc. Hort. Sci. 99(3):217220.

Waters, L., Jr., and B. Blanchette. 1983. Prediction of sweet corn field emergence by conductivity and cold tests. J. Amer. Soc. Hort. Sci. 108(5):778-781. 